\title{
EXPERIMENTAL INVESTIGATION OF LIQUID-LEVEL MEASURING ACCURACY IN A LOW PRESSURE ENVIRONMENT (U)
}

\section{Authors: Duane J. Adamson \\ M. R. Duignan}

October, 1996

\section{TECEIVED \\ MAY 261998 \\ OSTI}

\section{Westinghouse Savannah River Company Savannah River Technology Center Aiken, SC 29808}

Prepared for the U.S. Department of Energy under Contract DE-AC09-89SR18035

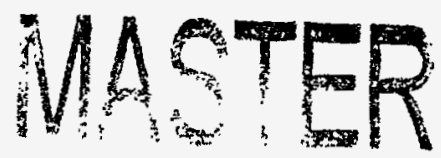

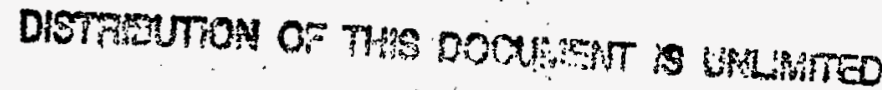

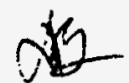




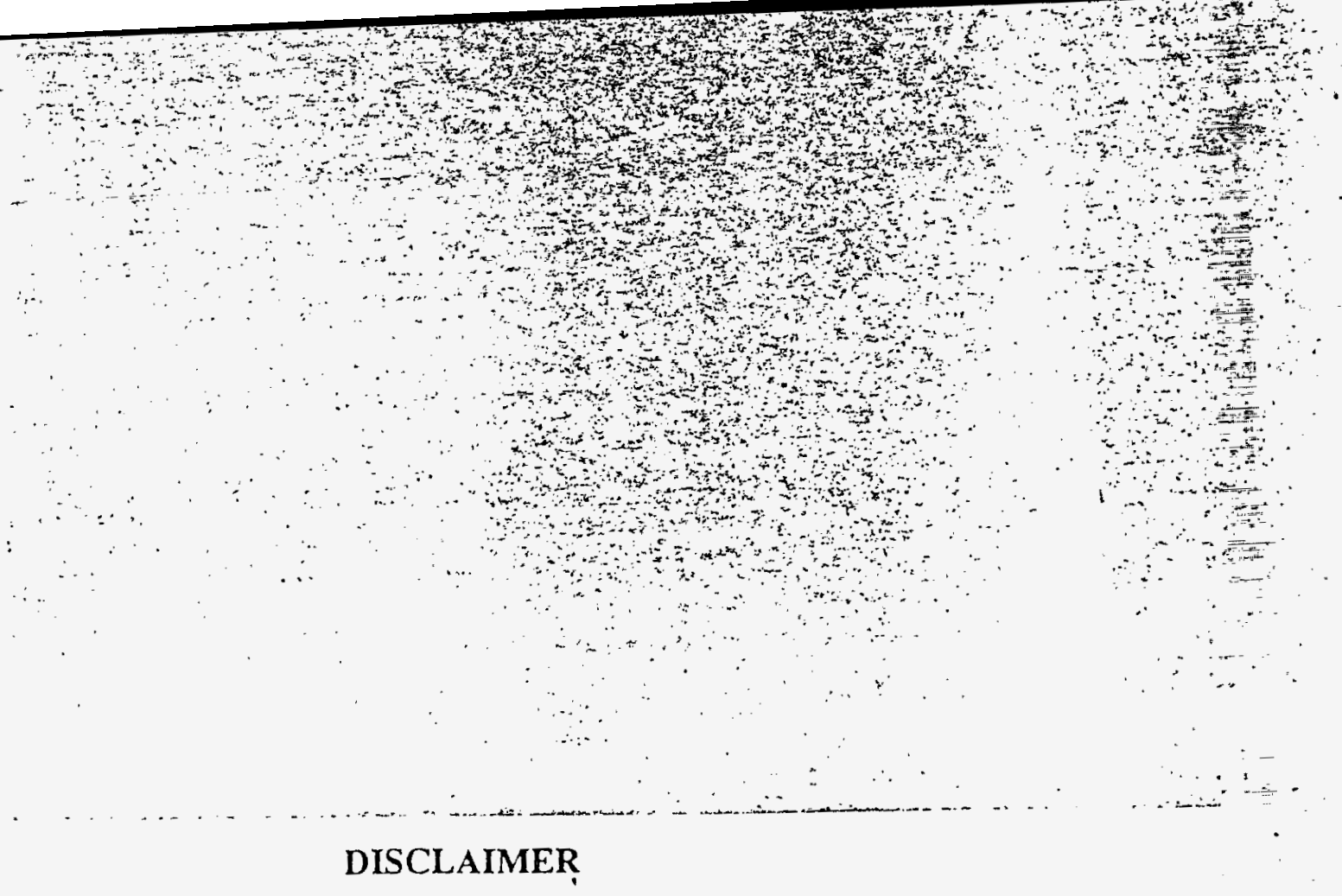

This report was prepared as an account of work sponsored by an agency of the United States Government. Neither the United States Government nor any agency thereof, nor any of their employees, makes any warranty, express or implied, or assumes any legal liability or responsibility for the accuracy, completeness, or usefulness of any information, apparatus, product, or process disclosed, or represents that its use would not infringe privately owned rights. Reference herein to any specific commercial product, process, or service by trade name, trademark, manufacturer, or otherwise does not necessarily constitute or imply its endorsement, recommendation, or favoring by the United States Government or any agency thereof. The views and opinions of authors expressed herein do not necessarily state or reflect those of the United States Government or any agency thereof.

This report has been reproduced directly from the best available copy.

Available to DOE and DOE contractors from the Office of Scientific and Technical Infornation, P.O. Box 62. Oak Ridge, IN 37831; prices available from (615) 576-8401.

Available to the public from the National Technical Information Service, U.S. Department of Commerce: 5285 Por Royal Road, Springfield, VA 22161. 


\section{DISCLAIMER}

Portions of this document may be illegible electronic image products. Images are produced from the best available original document. 


\author{
WSR C-TR -96-0251 \\ Task No.: SRT-ETF-960043 \\ KEYWORDS: \\ Dip Tubes \\ Am/Cm Feed Tank \\ Vacuum
}

RETENTION:

PERMANENT

Experimental Investigation of Liquid-Level
Measuring Accuracy In a Low Pressure Environment

by

D. J. Adamson

M. R. Duignan

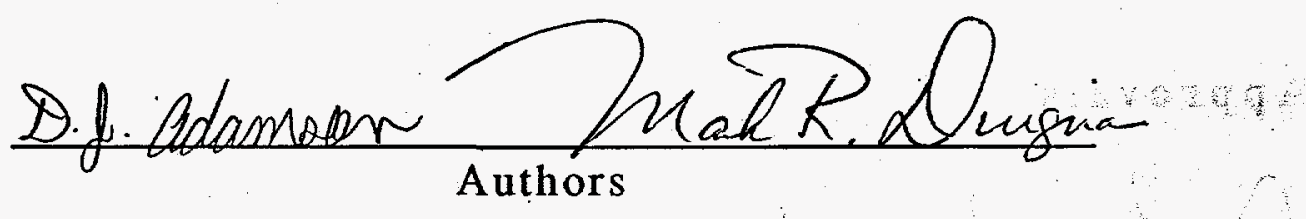

ISSUED: October, 1996

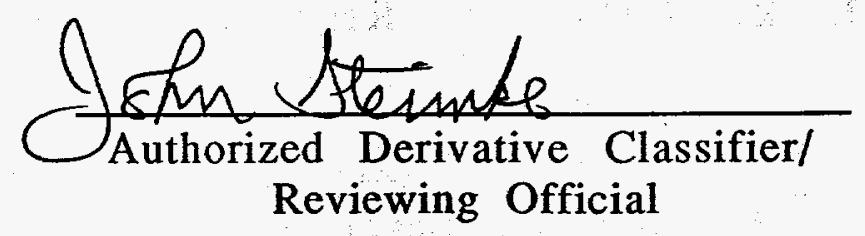

SRTC SAVANNAH RIVER TECHNOLOGY CENTER, AIKEN, SC 29808

Westinghouse Savannah River Company

Prepared for the U.S. Department of Energy under

Contract DE-AC09-89SR18035 
Document: WSRC-TR-96-0251

Title:

EXPERIMENTAL INVESTIGATION OF

LIQUID-LEVEL MEASURING ACCURACY

IN A LOW PRESSURE ENVIRONMENT (U)

Task:

SRT-ETF-960043

Approvals

$\frac{\text { Arth detanke } 10 / 8 / 96}{\text { L. Steimke, Technical Reviewer }}$
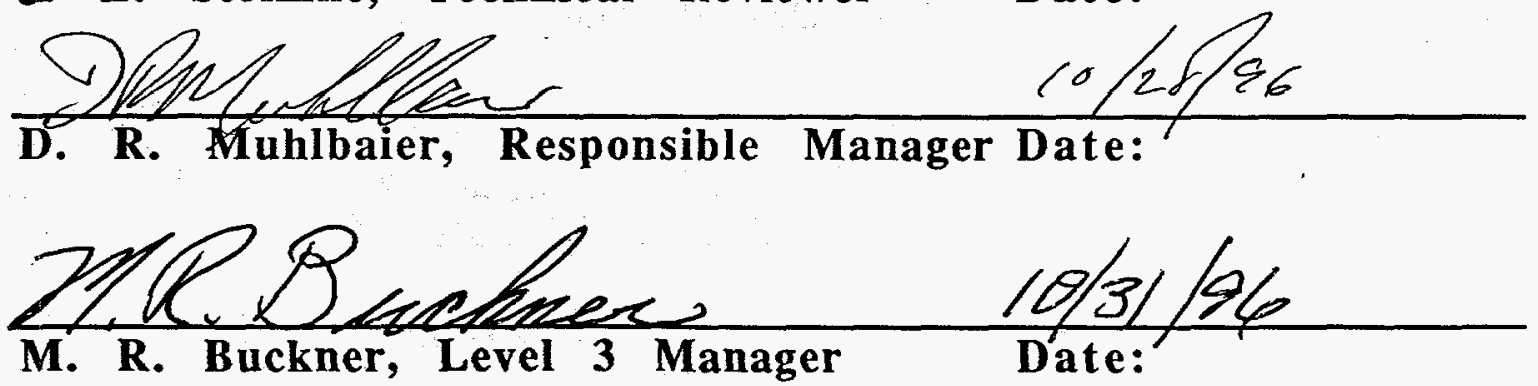
Report Revision Number

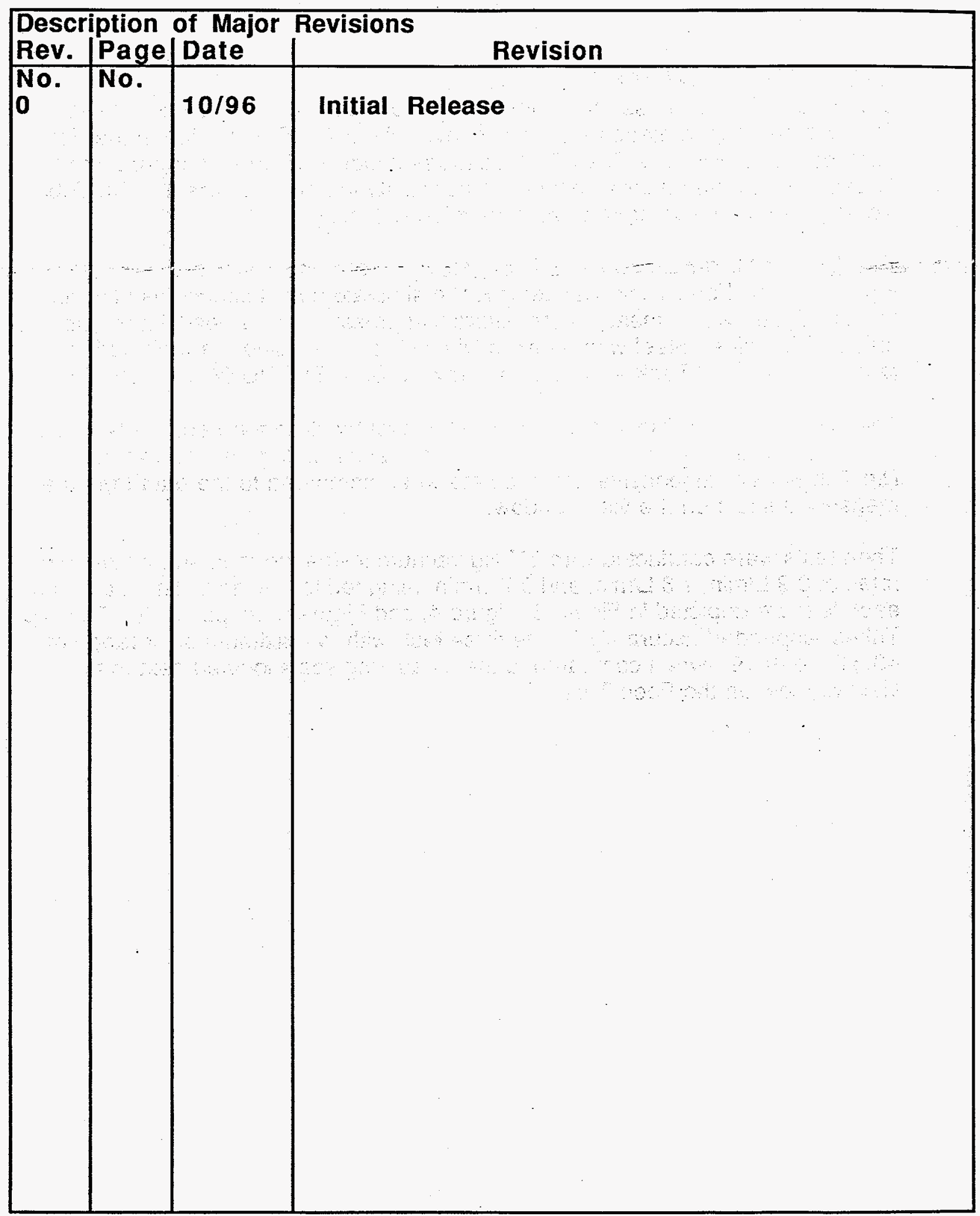




\section{EXECUTIVE SUMMARY}

Dip Tubes which are used for determining liquid level in many processes at SRS will be used to measure the liquid level of the $A m / C m$ solution in the Feed Tank at the MPPF. The Feed Tank operates under a vacuum, therefore the Dip Tubes will operate under a vacuum. Uncertainty in how accurate the Dip Tubes would perform in a vacuum environment led to testing.

-The Am/Cm Melter Liquid-Feed Tank measurement test was mocked-up per Figure 1. The Feed Tank was designed to simulate actual conditions in which the Dip Tubes would measure the differential pressure. The Feed Tank was made of Stainless Steel with a Lexan window to view inside the tank during testing. The Feed Tank was built per Drawing SRT-ETF-DD-96008, Revision A.

The accuracy of the Dip Tubes was checked first by filling the Feed Tank at a flow rate of $3.5 \mathrm{~L} / \mathrm{min}$ and venting it to the atmosphere. Figure 2 shows that the Dip Tubes were responsive and accurate when compared to the data from the measuring scale on the view window.

Then tests were conducted with $23^{\circ} \mathrm{Hg}$ vacuum inside the tank and water flow rates of $3.9 \mathrm{~L} / \mathrm{min}, 1.8 \mathrm{~L} / \mathrm{min}$, and $0.7 \mathrm{~L} / \mathrm{min}$ being fed to the tank. The data from each test are depicted in Figure 3, Figure 4, and Figure 5, respectively. The Dip Tubes responded accurately for the three test with a maximum error range of $+0.31^{\prime \prime}$ to $-0.19^{\circ}$ when compared to the measuring scale located next to the view window on the Feed Tank. 


\section{Table of Contents}

Executive Summary

Table of Contents

Introduction

Discussion

Test Loop

Instrumentation

Condensed Procedure

Results

Conclusion

References

List Of Figures:

Figure 1: Overall experimental test apparatus

Figure 2: $\quad$ Feed Tank Fluid Level Reading 3.5 L/min, no vacuum

Figure 3

Feed Tank Fluid Level Reading $3.9 \mathrm{~L} / \mathrm{min}, 23^{\circ} \mathrm{Hg}$ vacuum

Figure 4

Feed Tank Fluid Level Reading $1.8 \mathrm{~L} / \mathrm{min}, 23^{-} \mathrm{Hg}$ vacuum

Figure 5

Feed Tank Fluid Level Reading $0.7 \mathrm{~L} / \mathrm{min}, 23^{\circ} \mathrm{Hg}$ vacuum

Figure 6

Multimeter TR-3110 Calibration Data 


\section{INTRODUCTION}

Dip Tubes, sometimes called Liquid Level Bubblers, are used to measure liquid levels in many processes at SRS and will be used in the $A m / C m$ liquid. Feed Tank at the MPPF in F-Area. The transfer from the Am/Cm storage tank (17.3 tank) to the liquid Feed Tank will take place by a vacuum created in the Feed Tank. Due to uncertainty in how the Dip Tubes would respond in a vacuum environment led to testing at the Thermal Fluids Lab (TFL). The objective of the test was; to determine the accuracy of the Dip Tubes in a prototype Feed Tank under 23" of vacuum while filling the tank with water at various flow rates. Liquid level measurements were to be made at one minute intervals from the Dip Tubes and a measuring scale. To use a measuring scale, a view window was designed into the Feed Tank so that the liquid level on the inside of the tank could be viewed during the fill process.

\section{DISCUSSION}

\section{Test Loop}

The Am/Cm Liquid Feed Tank Measuring Tests were conducted in the Thermal Fluids Lab. The system was mocked up as shown in Figure 1. The Feed Tank was constructed of Stainless Steel with a Lexan window on one end so that the liquid level could be viewed inside the tank. Supports were welded on the inside of the tank to prevent the tank from deforming under vacuum. The dimensions of the tank are $26^{\prime \prime} \times 34.69^{\prime \prime} \times 2.5^{\prime \prime}$. For details of the design/construction of the Feed Tank see Drawing SRT-ETF-DD-96008, Revision A.

The short leg of the Liquid Level Dip Tubes was inserted in the top of the tank 1.31". The long leg is inserted 34.09" into the tank from the top of the tank (or 0.6 " off the bottom of the tank). The differential pressure of the Dip Tubes were read by a calibrated Pressure Transducer (TR-3110). The Pressure Transducer sent a 4 - 20 mAmp signal to a calibrated HP Multimeter (TR-2731). A measuring scale (tape measure) fixed to the view window was used to take visual measurements of the liquid level in tank.

The Vacuum Transducer Pump (Air Eductor) produced a maximum of $28^{\prime \prime} \mathrm{Hg}$ vacuum in the Feed Tank with a 80 psig air supply. Vacuum in the Feed Tank was reduced to $23^{\prime \prime} \mathrm{Hg}$ by adjusting (opening) the vent line valve. The air flowing through the transducer was released to the atmosphere in the TFL drain. The line was routed to the drain since there was a possibility of water getting in the vent line during the test. In the MPPF process this line is routed back to the 17.3 tank. A 2.0 Emergency Vent Valve was installed on the Liquid-Feed Tank to prevent the Feed Tank from accidentally being pressurized during the test. 


\section{Instrumentation}

Figure 6 shows the pressure transducer calibration data.

The line fit is:

$$
\Delta H=1.93(\mathrm{~mA})-7.71
$$

From this equation, inches of water was obtained from the current reading of the Multimeter.

The Pressure Transducer which measured the $\triangle \mathrm{P}$ between the short and long legs of the Dip Tubes was manufactured by Rosemount, Model 1151 DP. The pressure Transducer sent a 4 - 20 mAmp signal to a Hewlett Packard (HP) Multimeter, model 3457A where data from the Dip Tubes were obtained.

$A 0^{\prime \prime}$ to $30^{\prime \prime} \mathrm{Hg}$ Vacuum gauge, model PG-73, Manufacturer Marsh, was used to measure the pressure in the Feed Tank. The 2.0" Emergency Vent Valve, Model $7802 \mathrm{H} / 0038$ was installed on the Liquid-Feed Tank to prevent the Feed Tank from accidentally being pressurized during the test. The valve was built by The Protectoseal Company and has a set pressure of $17.3^{\prime \prime}$ of $\mathrm{H}_{2} \mathrm{O}$. The valve is planned to be used in the MPPF.Am/Cm Vitrification System.

The Vacuum Transducer Pump (VTP), model AV147H manufactured by Air Vac Engineering Company is essentially a air Eductor. The VTP produced a maximum of $28^{-1} \mathrm{Hg}$ vacuium in the Feed Tank with a $80 \mathrm{psig}$ air supply. Maximum vacuum that can be produced by the VTP with a 80 psig air supply is $28.5^{\prime \prime} \mathrm{Hg}$.

$\begin{array}{lllc}\text { Equipment } & \text { M\&TE } & \text { Range } & \text { Accuracy } \\ \text { Pressure Transducer: } & \text { TR-3110 } & 0-31^{\circ} \mathrm{H}_{2} \mathrm{O} & \pm 0.15^{\circ} \mathrm{H}_{2} \mathrm{O} \\ \text { HP Multimeter: } & \text { TR-2731 } & 0-30 \mathrm{~mA} & \pm 0.04 \% \text { of reading } \\ \text { Stop Watch: } & \text { TR-2268 } & - & \pm 500 \mu \mathrm{sec} / \mathrm{sec} \\ \text { Rotameters: } & \text { N/A } & 0-2.5 \mathrm{scfh} & \pm 0.25 \mathrm{scfh} \\ \text { Vacuum Gage: } & \text { TR-3506 } & 0-30^{\circ} \mathrm{Hg} & \pm 0.5^{\circ} \mathrm{Hg} \\ \text { Measuring Scale } & \text { N/A } & 0-35^{\circ} & \pm 0.06^{\circ}\end{array}$

\section{Condensed Procedure}

Measurement testing of the liquid level inside the Feed Tank was conducted per approved procedure FP-673. Per the procedure, a Lab log was kept for conducting the test. Readings were taken at the same time from both the measuring scale and the HP multimeter at one minute intervals. House water was used to adjust the liquid level of the tank. The first test was conducted with the tank opened to atmosphere and a flow rate of $3.5 \mathrm{~L} / \mathrm{min}$ of water. The flow rate of the water was controlled by using a metering valve (see Figure 1). Following tests were conducted in the same manner except with $23^{\prime \prime} \mathrm{Hg}$ 
vacuum in the Feed Tank. The flow rate of liquid to the Feed Tank was stead at 3.9 L/min, $1.8 \mathrm{~L} / \mathrm{min}$, and $0.7 \mathrm{~L} / \mathrm{min}$ for each run. The vacuum in the tank was reduced from $28^{\prime \prime} \mathrm{Hg}$ vacuum by opening the vent valve (V-4).

\section{Results}

- The vacuum environment in the Feed Tank had no impact on the accuracy of the Dip Tubes when compared to measurements taken with the Feed Tank opened to the atmosphere.

- The Dip Tubes were accurate with a maximum error range of $+0.31^{\prime \prime}$ to $-0.19^{\prime \prime}$ when compared to the measuring scale in a $23^{\prime \prime} \mathrm{Hg}$ vacuum environment.

- The accuracy of the Dip Tubes were not affected by varying the flow rate of liquid into the Feed Tank.

- The Vacuum Transducer Pump (VTP) produced a maximum of $28^{\prime \prime} \mathrm{Hg}$ vacuum in the prototype Feed Tank.

Measurement testing was conducted with $23^{\prime \prime} \mathrm{Hg}$ vacuum supplied to the Feed Tank with flow rates of $3.9 \mathrm{~L} / \mathrm{min}, 1.8 \mathrm{~L} / \mathrm{min}$, and $0.7 \mathrm{~L} / \mathrm{min}$. The data is depicted in Figure 3, Figure 4, and Figure 5 respectively. The graphs represent data from the dip Tubes and the measuring scale as the Feed Tank is being filled. From the graphs one can see that the Dip Tubes responded accurately to the change in liquid level under $23^{\prime \prime} \mathrm{Hg}$ vacuum when compared to the measuring scale. ant? Change in flow rate of liquid to the tank had no impact on the accuracy of the Dip Tubes. The error range of the Dip Tubes was $+0.31^{\circ}$ to $-0.19^{\circ}$ in a $23^{\circ} \mathrm{m} . \mathrm{m}$ $\mathrm{Hg}$ vacuum environment. This error could possible be due to human error and $\mathrm{k}$. a $1 / 16^{\prime \prime}\left(0.062^{\prime \prime}\right)$ resolution of the measuring scale.

During shakedown of the system it was found that exhaust back pressure has a major impact on the operation of the VTP. Initially $1 / 4^{\prime \prime}$ (approximately $4 \mathrm{ft}$ long) tubing was used to route the exhaust from the VTP to the Drain where the gases would be released. The $1 / 4^{-1}$ tubing created a high back pressure causing the VTP to produce a pressure in the tank. 1/2" tubing (approximately $4 \mathrm{ft}$ long) was than used for the shake down. The $1 / 2$ tubing had no effect on the operation of the VTP and $28^{\prime \prime}$ of vacuum was produced in the Feed Tank. Shakedown was also conducted with a 1 inch tubing (approximately $4 \mathrm{ft}$ long) and no exhaust tubing on the VTP. There were no effects on the operation of the VTP with $28^{-1}$ of vacuum being produced in the Feed Tank.

\section{CONCLUSION}

The Feed Tank Dip Tubes were tested for accuracy under $23^{\prime \prime} \mathrm{Hg}$ vacuum at flow rates of $3.9 \mathrm{~L} / \mathrm{min}, 1.8 \mathrm{~L} / \mathrm{min}$, and $0.7 \mathrm{~L} / \mathrm{min}$ of water flowing in the tank. The tests concluded that the Dip Tubes responded accurately to the change in liquid level in the Feed Tank. Neither the vacuum environment or change in 
flow rate of liquid had an effect on the accuracy of the Dip Tubes as depicted in Figure 3 (page 9), Figure 4 (page 10), and Figure 5 (page 11).

The restriction of the exhaust line could have an effect on the operation of the Vacuum Transducer Pump (VTP). If a high back pressure is created in the exhaust line of the VTP, the VTP is unable to create a vacuum. Therefore the exhaust line from the VTP to the 17.3 tank should be analyzed or tested to ensure that operation of the system will not be affected.

\section{REFERENCES}

- Am/Cm Liquid Feed Tank Experimental Drawing, SRT-ETE-DD-96008, Rev A

- Liquid Feed Tank Measurement Test, Procedure FP-673, July 1996 
Figure 1

\section{Sketch of Equipment used in the Am/Cm Liquid Feed} Tank Measurement Test

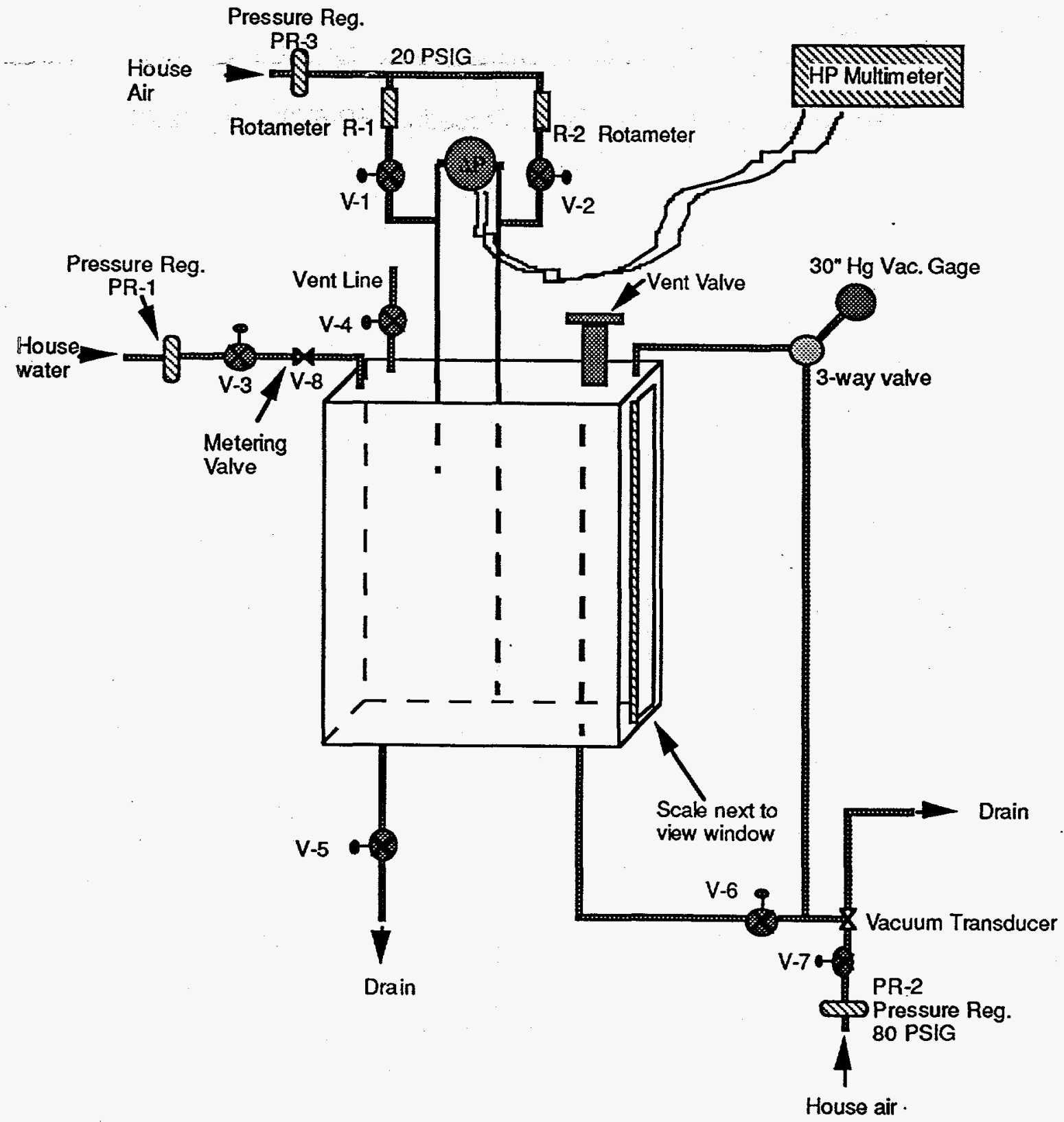


Figure 2

Feed Tank Fluid Level Reading

$3.5 \mathrm{t} / \mathrm{min}$, No Vacuum

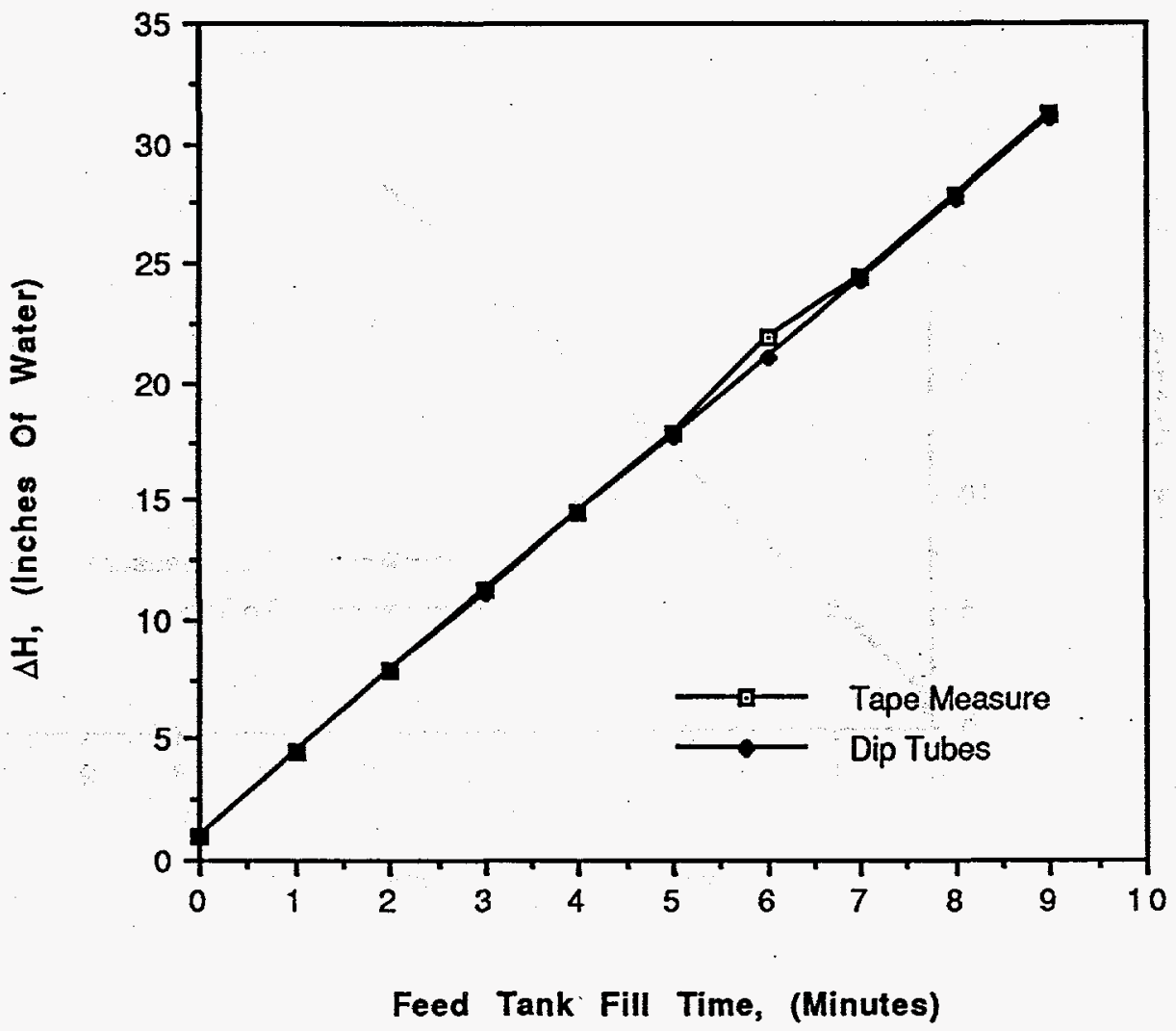


Figure 3

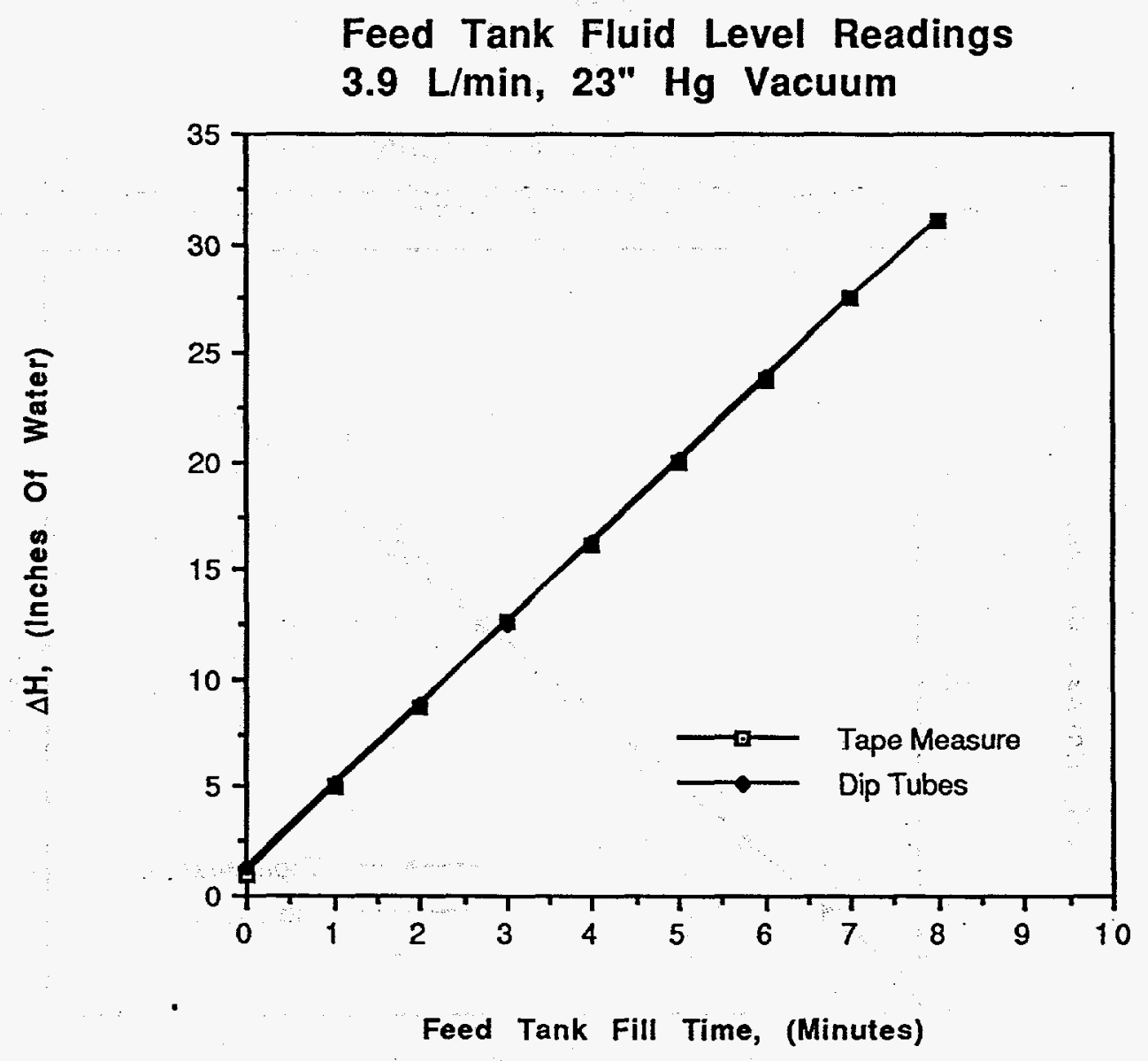


Figure 4

Feed Tank Fluid Level Readings

$1.8 \mathrm{~L} / \mathrm{min}, 23^{\circ "} \mathrm{Hg}$ Vacuum

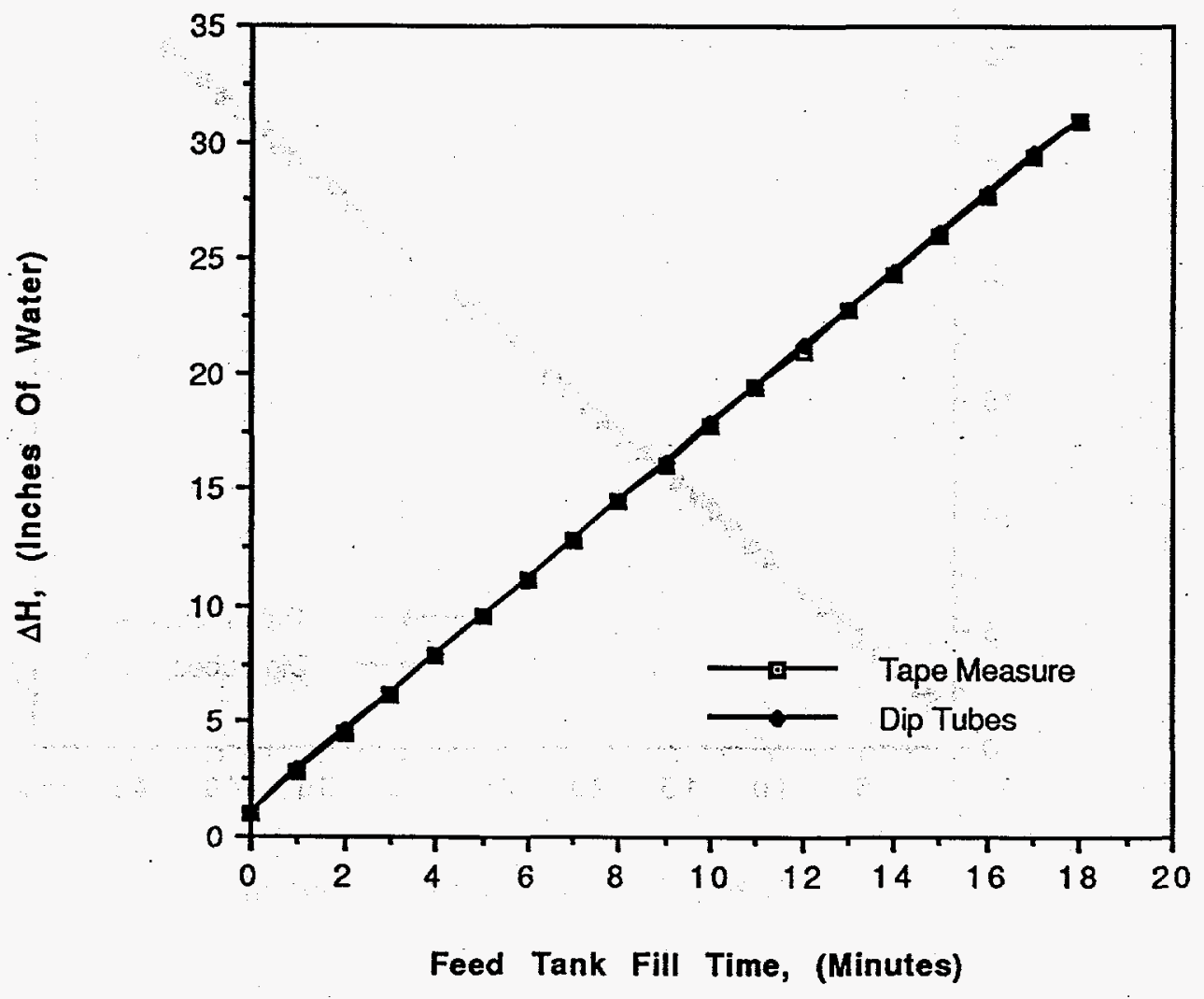


Figure 5

Feed Tank Fluid Level Readings

$0.7 \mathrm{~L} / \mathrm{min}, 23 " \mathrm{Hg}$ Vacuum

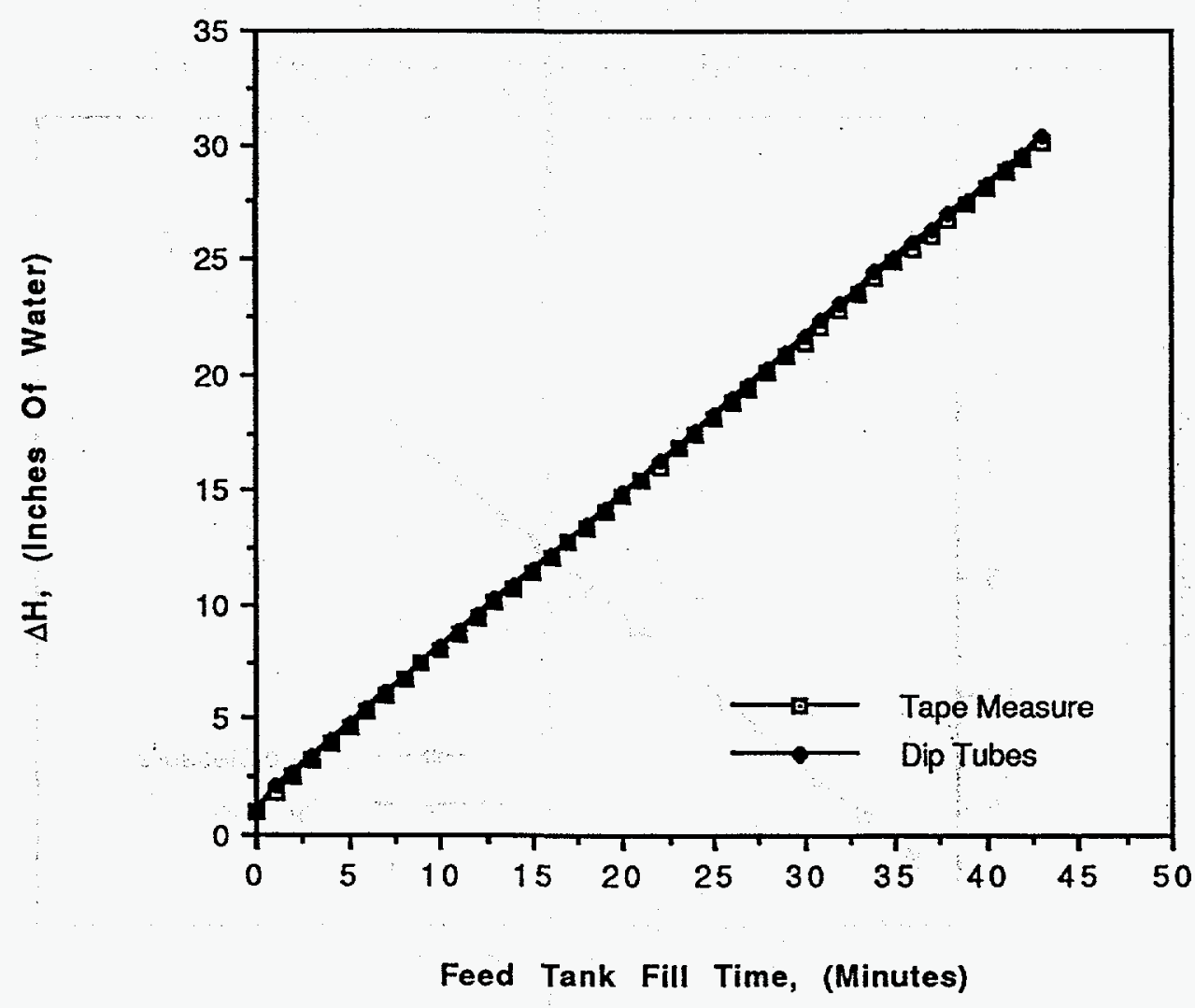


Figure 6

\section{Pressure Transducer (TR-3110) Calibration Data}

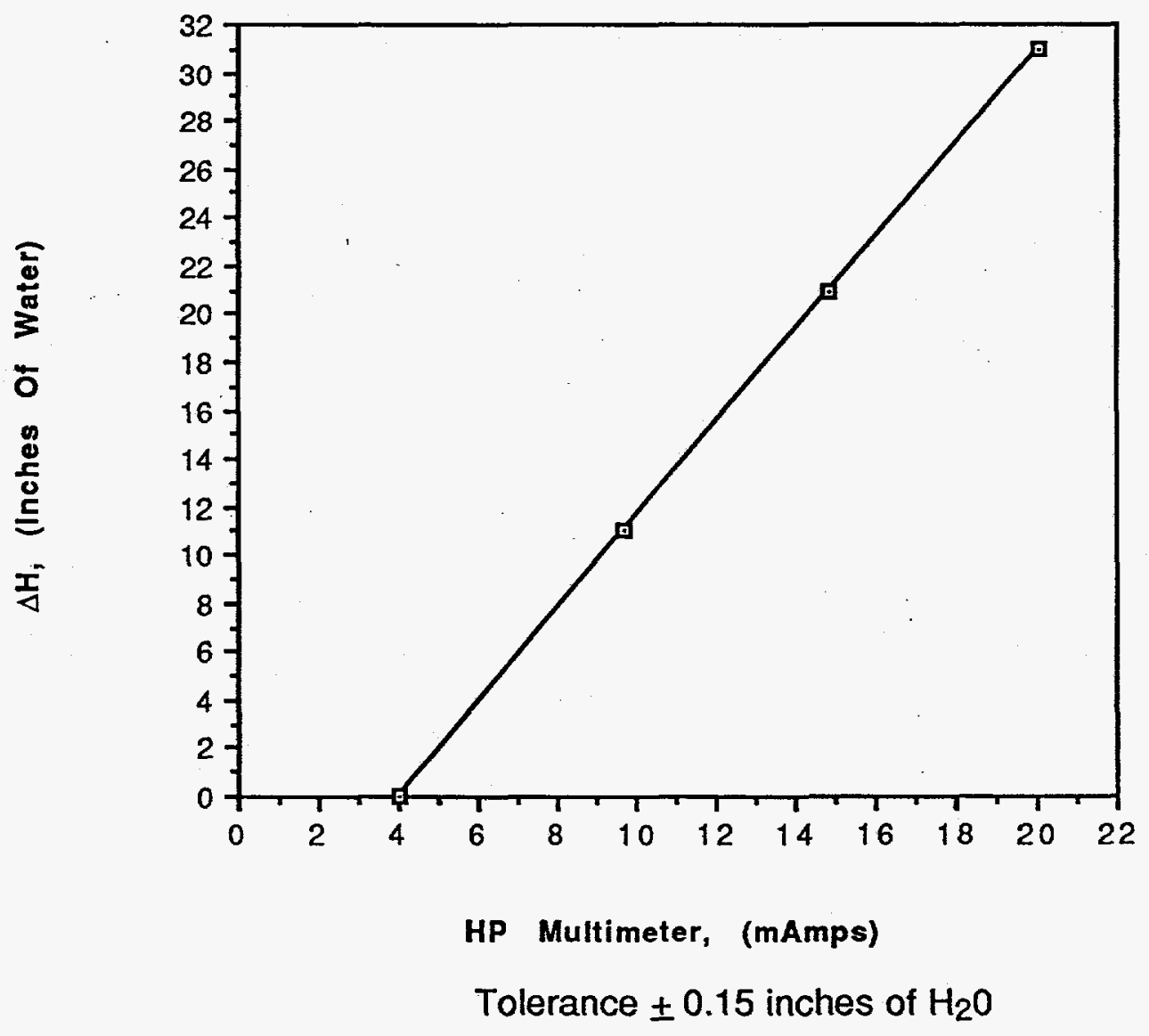

